Wahana Didaktika Vol. 19 No.1 Januari 2021 : 68-80

\title{
PENERAPAN MODEL PEMBELAJARAN KOOPERATIF TIPE DISCOVERY LEARNING DALAM MENINGKATKAN HASIL BELAJAR IPA SISWA SD NEGERI 170 PALEMBANG
}

\author{
Oleh: Ermawati \\ Email: ermawati@gmail.com \\ (SD Negeri 170 Palembang)
}

\begin{abstract}
Abstrak
Tujuan dari penelitian tindakan ini adalah untuk mengetahui peningkatan hasil belajar peserta didik setelah diterapkannya Model Pembelajaran Kooperatif Tipe Discovery Learning. Penelitian ini menggunakan penelitian tindakan (classroom action research) sebanyak dua putaran. Setiap putaran terdiri dari empat tahap yaitu: rancangan, kegiatan dan pengamatan, refleksi, dan revisi. Sasaran penelitian ini adalah peserta didik kelas IV.B SD Negeri 170 Palembang yang berjumlah 30 peserta didik. Data yang diperoleh berupa hasil tes formatif, lembar observasi kegiatan belajar mengajar dan dokumentasi. Dari hasil analis didapatkan bahwa hasil belajar peserta didik mengalami peningkatan yang signifikan ditandai dengan peningkatan ketuntasan belajar peserta didik dalam setiap siklusnya, yaitu siklus I (69\%) dan (79\%) pada siklus II. Kesimpulan dari penelitian ini adalah model pembelajaran kooperatif tipe Discovery Learning dapat berpengaruh positif terhadap hasil belajar peserta didik SD Negeri 170 Palembang, serta model pembelajaran ini dapat digunakan sebagai salah satu alternatif dalam upaya perbaikan pembelajaran IPA.
\end{abstract}

Kata Kunci: Hasil Belajar IPA, Model Pembelajaran Kooperatif Tipe Discovery Learning

\section{APPLICATION OF DISCOVERY LEARNING TYPE COOPERATIVE LEARNING MODELS IN IMPROVING SCIENCE LEARNING RESULTS STUDENTS SD NEGERI 170 PALEMBANG}

\begin{abstract}
The purpose of this action research is to determine the increase in student learning outcomes after the implementation of the Cooperative Learning Model Discovery Learning Type. This study uses two rounds of action research (classroom action research). Each round consists of four stages, namely: design, activities and observations, reflection, and revision. The target of this research is students of class IV.B SD Negeri 170 Palembang, amounting to 30 students. The data obtained are in the form of formative test results, observation sheets for teaching and learning activities and documentation. From the results of the analysis, it was found that the learning outcomes of students had a significant increase marked by an increase in students' learning completeness in each cycle, namely cycle I (69\%) and (79\%) in cycle II. The conclusion of this research is that the cooperative learning model Discovery Learning can have a positive effect on
\end{abstract}


Penerapan Model Pembelajaran ....(Ermawati)

the learning outcomes of students at SD Negeri 170 Palembang, and this learning model can be used as an alternative in an effort to improve science learning.

Keywords: IPA Learning Outcomes, Cooperative Learning Model Type Discovery Learning,

\section{A. PENDAHULUAN}

Ilmu Pengetahuan Alam (IPA) berhubungan dengan cara mencari tahu tentang alam secara sistematis, sehingga IPA bukan hanya penguasaan kumpulan pengetahuan yang berupa fakta-fakta, konsep-konsep atau prinsip-prinsip saja tetapi juga merupakan suatu proses penemuan. Mata pelajaran IPA di SD bertujuan agar peserta didik memiliki kemampuan mengembangkan rasa ingin tahu, sikap positif dan kesadaran tentang adanya hubungan yang saling mempengaruhi antara IPA, lingkungan, teknologi dan masyarakat.

Selama ini pelaksanaan pembelajaran IPA di SD Negeri 170 Palembang, peneliti menggunakan metode ceramah, tanya jawab, diskusi, tugas belajar, dan kerja kelompok. Dalam proses pembelajaran menggunakan metode ceramah peneliti menyadari kegiatannya masih berpusat pada guru. Siswa hanya mendengarkan materi kemudian mengerjakan latihan soal ataupun kerja kelompok. Kemampuan siswa untuk mengamati, menggolongkan, menggunakan alat, menerapkan konsep, mengkomunikasikan dan mengajukan pertanyaan belum terasah secara maksimal. Pembelajaran IPA belum mampu mengembangkan keterampilan proses siswa. Metode ceramah kurang membuat siswa aktif di dalam pembelajaran sehingga menimbulkan kejenuhan pada siswa.

Dari metode yang telah peneliti gunakan hanya beberapa siswa yang aktif dalam pembelajaran. Hal tersebut membuat siswa kurang mengembangkan pengetahuan, keterampilan proses dan memahami konsep IPA. Oleh karena itu, perlu adanya upaya untuk meningkatkan keterampilan proses dalam pembelajaran IPA. Rendahnya hasil belajar yang diperoleh peserta didikini dipengaruhi oleh faktor eksternal. Salah satunya metode atau cara yang digunakan guru dalam pembelajaran IPA khususnya materi tentang Energi dan Penggunaannya masih kurang efektif sehingga materi yang disampaikan kurang menarik. 
Rendahnya hasil belajar peserta didik juga dipengaruhi oleh kurangnya minat, motivasi dan perhatian peserta didik terhadap materi pelajaran yang disampaikan sehingga peserta didik merasa kesulitan dalam menerima materi pelajaran dan peserta didik juga kesulitan dalam menyelesaikan tugas-tugas yang diberikan oleh guru. Hal ini tentu belajar yang akan diperoleh peserta didik. Salah satu cara untuk mengatasi kendala-kendala yang dihadapipeserta didikdiatas mungkin dapat dilakukan pengubahan model pembelajaran, mencari model belajar yang membuat peserta didik tertarik untuk belajar.

Dalam pemilihan model pembelajaran, seorang guru harus menyesuaikan nya dengan kondisi kelas dan materi pelajaran yang akan disampaikan agar peserta didik menjadi lebih aktif dan terampil, agar hasil belajar pun ikut meningkat. Salah satu model pembelajaran yang diharapkan dapat memotivasi peserta didik dalam meningkatkan hasil belajar adalah model pembelajaran kooperatif. Model pembelajaran kooperatif merupakan strategi pembelajaran kelompok yang akhir-akhir ini menjadi salah satu alternatif yang sering digunakan. Belajar dalam kelompok lebih baik dilakukan dari pada belajar sendiri-sendiri, karena dalam kelompok peserta didik dapat saling membantu dalam memahami apa yang mereka pelajari (Murni, dkk, 2009, p.11) model pembelajaran kooperatif yang sesuai dengan mata pelajaran IPA adalah model pembelajaran kooperatif tipe Discovery Learning.

Berdasarkan Latar belakang masalah diatas, maka rumusan masalah dalam penelitian ini adalah apakah model pembelajaran kooperatif tipe Discovery Learning dapat meningkatkan hasil belajar IPA dalam pada peserta didik kelas IV SD Negeri 170 Palembang”. Sesuai dengan permasalahan di atas, penelitian ini bertujuan "untuk mengetahui peningkatan hasil belajar IPA melalui model pembelajaran kooperatif tipe Discovery Learning pada peserta didik kelas IV SD Negeri 170 Palembang".

Menurut Romine seperti dikutip Hamalik (2008:106) berpendapat bahwa "learning is defined as the modification or strengthening of behavior through experiencing”. Pandangan ini berpendapat bahwa belajar merupakan suatu proses dan bukan hasil yang hendak dicapai. Proses itu sendiri berlangsung melalui 
serangkaian pengalaman sehingga terjadi modifikasi pada tingkah laku yang telah dimiliki sebelumnya. Jadi, berdasarkan proses (sebagai alat atau means) akan tercapai tujuan (ends), sesuatu hal yang dikehendaki oleh pendidikan.

Winkel W.S. (1991:35) berpendapat bahwa belajar merupakan kegiatan mental yang tidak dapat disaksikan dari luar. Artinya, apa yang sedang terjadi dalam diri seseorang yang sedang belajar tidak dapat diketahui secara langsung hanya dengan mengamati orang itu. Bahkan, hasil belajar orang itu tidak langsung kelihatan, tanpa orang itu melakukan sesuatu yang menampakkan kemampuan yang telah diperoleh melalui belajar.

Lalu masih dalam buku yang sama, Winkel W.S. (1991:36) dalam kesimpulannya mengenai belajar mengatakan bahwa belajar merupakan suatu aktivitas mental atau psikis yang berlangsung dalam interaksi aktif dengan lingkungan, yang sebagai prinsip umum atau kumpulan prinsip yang saling berhubungan dan merupakan penjelasan atas sejumlah fakta dan penemuan yang berkaitan dengan peristiwa belajar.

Dalam pandangan konstruktivisme "Belajar" bukanlah semata-mata mentransfer pengetahuan yang ada diluar dirinya, tetapi belajar lebih pada bagaimana otak memproses dan menginterpretasikan pengalaman yang baru dengan pengetahuan yang sudah dimiliknya dalam format yang baru (Trianto, 2009, p.15). Belajar pada hakikatnya juga merupakan proses interaksi terhadap semua situasi yang ada disekitar individu. Belajar dipandang sebagai proses yang diarahkan kepada tujuan dan proses berbuat melalui berbagai pengalaman.

Istilah pembelajaran merupakan terjemahan dari kata instruction, mempunyai pengertian serangkaian kegiatan yang dirancang untuk memungkinkan terjadinya proses belajar pada siswa. Pembelajaran dapat diartikan bahwa proses belajar dalam diri siswa terjadi, baik karena ada yang secara langsung mengajar (guru) ataupun secara tidak langsung (siswa secara aktif berinteraksi dengan media atau sumber belajar yang lain) (Sardiman, 2005, p.5).

Hamalik (2011, p.55) dalam bukunya berjudul Kurikulum dan pembelajaran "pembelajaran adalah suatu kombinasi yang tersusun meliputi 
unsur-unsur manusiawi, material, fasilitas, perlengkapan dan prosedur yang saling mempengaruhi dalam mencapai tujuan pembelajaran".

Selanjutnya, Slameto (2010, p.3) menyatakan hasil belajar sebagai perubahan yang terjadi dalam diri seseorang berlangsung secara berkesinambungan, tidak statis. Satu perubahan yang terjadi akan menyebabkan perubahan berikutnya dan akan berguna bagi kehidupan ataupun proses belajar berikutnya. Hasil belajar yang dicapai peserta didik dipengaruhi dua faktor utama yakni faktor lingkungan dan faktor yang datang dari diri peserta didik itu sendiri terutama kemampuan yang dimilikinya.

Ilmu Pengetahuan Alam atau IPA menurut James B. Conan (dalam Samantowa, 2011, p.1) didefinisikan sebagai suatu deretan konsep serta skema konseptual yang berhubungan satu sama lain, dan yang tumbuh sebagai hasil eksperimentasi dan observasi, serta berguna untuk diamati dan di eksperimentasikan lebih lanjut. Selanjutnya, Winaputra (dalam Samantowa, 2011, p.3) mengemukakan bahwa IPA tidak hanya merupakan kumpulan pengetahuan tentang benda atau makhluk hidup, tetapi merupakan cara kerja, cara berfikir, dan cara pemecahan masalah.

Pembelajaran kooperatif (Cooperative Learning) merupakan suatu model pembelajaran dimanapeserta didikbelajar dalam kelompok-kelompok kecil yang memiliki tingkat kemampuan yang berbeda (Ibrahim, 2009, p.11). Discovery Learning adalah metode mengajar yang mengatur pengajaran sedemikian rupa sehingga anak memperoleh pengetahuan yang sebelumnya belum diketahuinya tanpa pemberitahuan langsung; sebagian atau seluruhnya ditemukan sendiri. Teknik penemuan adalah terjemahan dari discovery. Dengan menggunakan discovery learning ialah suatu cara mengajar yang melibatkan peserta didik dalam proses kegiatan mental melalui tukar pendapat, dengan diskusi, seminar, membaca sendiri dan mencoba sendiri agar anak dapat belajar sendiri.

\section{B. METODOLOGI PENELITIAN}

Model penelitian yang digunakan dalam penelitian ini adalah Penelitian Tindakan Kelas (PTK) yang bertujuan untuk meningkatkan hasil belajar peserta 
Penerapan Model Pembelajaran ....(Ermawati)

didik. Sanjaya (2009, p.26) menyatakan bahwa Penelitian Tindakan Kelas (PTK) dapat diartikan sebagai proses pengkajian masalah pembelajaran di dalam kelas melalui refleksi diri dalam upaya untuk memecahkan masalah tersebut dengan cara melakukan berbagai tindakan yang terencana dalam situasi nyata serta menganalisis setiap pengaruh dari perlakuan tersebut.

Menurut Oja dan Smulyan sebagaimana dikutip oleh Sukidin, dkk (200, p.55), ciri-ciri dari setiap penelitian tergantung pada: (1) tujuan utamanya atau pada tekanannya, (2) tingkat kolaborasi antara pelaku peneliti dan peneliti dari luar, (3) proses yang digunakan dalam melakukan penelitian, dan (4) hubungan antara proyek dengan sekolah.

Lokasi penelitian tindakan kelas ini dilaksanakan di SD Negeri 170 Palembang, provinsi Sumatera Selatan. Penelitian ini dilaksanakan pada Februari s/d April 2019 Tahun Pelajaran 2018/2019. Subjek penelitian ini adalah peserta didik kelas IV SD Negeri 170 Palembang yang berjumlah 30 peserta didik. pokok bahasan yang disampaikan mengenai materi "Energi dan Penggunaannya".

Indikator keberhasilan penelitian ini menggunakan nilai hasil pembelajaran peserta didik saat melaksanakan siklus I dan II, yakni apabila secara klasikal $85 \%$ peserta didik telah memperoleh nilai minimal 70 (KKM) pada mata pelajaran IPA. Model penelitian yang digunakan adalah model penelitian yang dikembangkan oleh Kemmis dan Mc Tagart yang dikutip Arikunto (2006, p.98) terdiri atas empat tahap, yaitu: 1) Menyusun Rancangan Tindakan (Planning), 2) Pelaksanaan Tindakan (Acting), 3) Pengamatan (Observing), 4) Refleksi (Reflecting)

\section{HASIL PENELITIAN DAN PEMBAHASAN}

\section{Pra siklus}

Menerapkan model pembelajaran kooperatif tipe Discovery Learning diperoleh nilai rata-rata hasil belajar siswa adalah 60.67 dan ketuntasan belajar mencapai $28.13 \%$ atau ada 9 siswa dari 30 siswa sudah tuntas belajar. Hasil tersebut menunjukkan bahwa pada pra siklus secara klasikal siswa belum tuntas belajar, karena siswa yang memperoleh nilai $\geq 70$ hanya sebesar $28.13 \%$ lebih 
kecil dari persentase ketuntasan yang dikehendaki yaitu sebesar $85 \%$. Hal ini disebabkan karena siswa masih merasa baru dan belum mengerti apa yang dimaksudkan dan digunakan guru dengan menerapkan metode model pembelajaran kooperatif tipe Discovery Learning.

\section{Siklus I}

\section{a. Perencanaan}

Pada siklus I guru membuat rencana pembelajaran dan menggunakannya sesuai skenario yang sudah dibuat. Pembelajaran dilaksanakan dengan menerapkan model pembelajaran kooperatif tipe Discovery Learning, yang meliputi: apersepsi, eksplorasi, diskusi dengan penjelasan, dan pengembangan. Guru mengkondisikan siswa agar siap mengikuti kegiatan pembelajaran, guru membawa siswa untuk mengungkapkan hal-hal yang pernah dipelajari sebelumnya dan menanyakan secara langsung tentang konsep dasar mendeskripsikan energi panas dan bunyi yang terdapat di lingkungan sekitar serta sifat-sifatnya.

\section{b. Pelaksanaan}

Guru membuka proses pembelajaran dengan salam.Guru memulai dengan membaca doa.Guru mengabsen kehadiran siswa. Guru mengulang pelajaran sebelumnya Guru membentuk pembelajaran di kelas dengan suasana berkelompok yang di bantu oleh pengamat. Guru membagi peserta didik menjadi 5 kelompok. Masing-masing kelompok berjumlah 6 atau 7 peserta didik. Setelah peserta didik menempati posisinya, guru meminta salah satu perwakilan dari masing-masing kelompok untuk mengambil lembar kerja serta alat dan bahan yang telah disiapkan oleh guru.

Guru menjelaskan pada peserta didik cara pengerjaan lembar kerja dan meminta peserta didikutuk berdiskusi dan bekerja sama dengan anggota kelompoknya guna memecahkan persoalan yang ada dalam lembar kerja. Lembar kerja ini diberikan untuk mempermudah peserta didik mencapai tujuan pembelajaran dengan menerapkan Discovery Learning.

Peserta didik melakukan diskusi dengan bimbingan guru. Kegiatan selanjutnya yaitu presentasi yang dapat melatih peserta didik untuk berani tampil 
di depan teman-temannya dalam mempresentasikan hasil diskusinya. Pada akhir pembelajaran peserta didik diberi tes akhir. Siswa dibimbing guru menyimpulkan kegiatan pembelajaran Siswa mengerjakan soal evaluasi yang diberikan guru. Guru memberikan motivasi untuk rajin belajar. Guru menutup kegiatan pembelajaran dengan mengucapkan salam

\section{c. Observasi}

Hasil belajar siklus I ini merupakan data awal penelitian dengan menerapkan model pembelajaran kooperatif tipe Discovery Learning secara umum hasil belajar pokok bahasan mendeskripsikan energi panas dan bunyi yang terdapat di lingkungan sekitar serta sifat-sifatnya dapat dilihat pada tabel sebagai berikut:

Tabel 1 Hasil Belajar Siklus I

\begin{tabular}{|lll|}
\hline Jumlah Nilai & $=$ & 2070 \\
\hline Jumlah Nilai Maksimal ideal & $=$ & 3200 \\
\hline Rata-rata Nilai Tercapai & $=$ & 69.00 \\
\hline Jumlah siswa yang belum tuntas & $=$ & 11 \\
\hline Jumlah siswa yang tuntas & $=$ & 19 \\
\hline Persentase Belum tuntas & $=$ & 34.38 \\
\hline Persentase ketuntasan & $=$ & 59.38 \\
\hline Klasikal & $=$ & Belum Tuntas \\
\hline
\end{tabular}

Berdasarkan tabel di atas menunjukkan bahwa hasil belajar siswa kelas IV SD Negeri 170 Palembang pada materi Energi dan Penggunaannya setelah menggunakan model pembelajaran kooperatif tipe Discovery Learning mencapai rata-rata kelas sebesar 69 dalam kategori belum tuntas. Dengan menerapkan model pembelajaran kooperatif tipe Discovery Learning diperoleh nilai rata-rata hasil belajar siswa adalah 69 dan ketuntasan belajar mencapai 59,38 \% atau ada 19 siswa dari 30 siswa sudah tuntas belajar. Hasil tersebut menunjukkan bahwa pada siklus pertama secara klasikal siswa belum tuntas belajar, karena siswa yang memperoleh nilai $\geq 70$ hanya sebesar $59.38 \%$ lebih kecil dari persentase ketuntasan yang dikehendaki yaitu sebesar $85 \%$. Hal ini disebabkan karena siswa masih merasa baru dan belum mengerti apa yang dimaksudkan dan digunakan 
guru dengan menerapkan model pembelajaran kooperatif tipe Discovery Learning.

\section{d. Refleksi}

Ada beberapa siswa yang nilainya rendah karena siswa kurang memperhatikan penjelasan guru. Saat pembelajaran siswa kurang merespon pertanyaan dari guru dan berani bertanya mengenai materi yang belum dipahami. Guru kurang menguasai dalam penyampaian materi sehingga siswa banyak yang tidak memahami materi pembelajaran. Guru kurang menggunakan media secara efektif dand efisien. Suasana kelas sedikit ramai bila ada waktu luang, karena siswa lebih banyak suka bergurau daripada belajar sendiri dikelas walau ada waktu luang yang diberikan oleh guru kelas pada waktu guru sedang meninggalkan kelas. Keemampuan guru mengelola waktu masih kurang, disebabkan karena guru tidak hanya mengajar, tetapi ada kegiatan lain.

\section{Siklus II}

\section{a. Perencanaan}

Pada siklus II guru membuat rencana pembelajaran dan menggunakannya sesuai skenario yang sudah dibuat. Pembelajaran dilaksanakan dengan menerapkan model pembelajaran kooperatif tipe Discovery Learning. Guru mengkondisikan siswa agar siap mengikuti kegiatan pembelajaran. Guru membawa siswa untuk mengungkapkan hal-hal yang pernah dipelajari sebelumnya dan menanyakan secara langsung tentang materi energi dan penggunaannya.

\section{b. Pelaksanaan}

Guru membentuk pembelajaran di kelas dengan suasana berkelompok yang di bantu oleh pengamat. Guru membagi peserta didik menjadi 5 kelompok. Masing-masing kelompok berjumlah 6 atau 7 peserta didik. Setelah peserta didik menempati posisinya, guru meminta salah satu perwakilan dari masing-masing kelompok untuk mengambil lembar kerja serta alat dan bahan yang telah disiapkan oleh guru.

Guru menjelaskan pada peserta didik cara pengerjaan lembar kerja dan meminta peserta didikutuk berdiskusi dan bekerja sama dengan anggota 
kelompoknya guna memecahkan persoalan yang ada dalam lembar kerja. lembar kerja ini diberikan untuk mempermudah peserta didik mencapai tujuan pembelajaran dengan menerapkan Discovery Learning. Dalam kelompok peserta didik diharapkan bisa menemukan materi berdasarkan kegiatan yang telah dilakukan. Peserta didik melakukan diskusi dengan bimbingan guru. Kegiatan selanjutnya yaitu presentasi yang dapat melatih peserta didik untuk berani tampil di depan teman-temannya dalam mempresentasikan hasil diskusinya.

\section{c. Observasi}

Hasil belajar pada siklus II mengalami peningkatan di banding dengan siklus I, yang semula siklus I rata-ratanya 69 pada siklus II meningkat menjadi 79,00. Lebih jelas dapat dilihat pada tabel di bawah ini:

Tabel 2 Hasil Belajar Siklus II

\begin{tabular}{|lll|}
\hline Jumlah Nilai & $=$ & 2370 \\
\hline Jumlah Nilai Maksimal ideal & $=$ & 3200 \\
\hline Rata-rata Nilai Tercapai & $=$ & 79.00 \\
\hline Jumlah siswa yang belum tuntas & $=$ & 2 \\
\hline Jumlah siswa yang tuntas & $=$ & 28 \\
\hline Persentase Belum tuntas & $=$ & 6.25 \\
\hline Persentase ketuntasan & $=$ & 87.50 \\
\hline Klasikal & $=$ & Tuntas \\
\hline
\end{tabular}

Berdasarkan tabel di atas menunjukkan bahwa hasil belajar siswa kelas IV SD Negeri 170 Palembang pada materi energi dan penggunaannya setelah menggunakan metode model pembelajaran kooperatif tipe Discovery Learning mencapai rata-rata 79. Sehingga dapat disimpulkan bahwa peningkatan hasil belajar dengan menggunakan model pembelajaran kooperatif tipe Discovery Learning semakin membaik. Berdasarkan diagram di atas dapat disimpulkan bahwa hasil belajar siswa mengalami peningkatan yang baik. Pada siklus I yang semula rata-ratanya 69 menjadi 79 pada siklus II.

\section{d. Refleksi}

Pelaksanaan siklus II berpedoman pada rencana pembelajaran sikus II yang telah dibuat. Pada siklus II ini berdasarkan pengamatan kegiatan guru melakukan pembelajaran dengan menggunakan model pembelajaran kooperatif 
tipe Discovery Learning dalam kategori baik. Pengamatan terhadap siswa juga mengalami kemajuan dari pada siklus I. Pada siklus II mencapai 83,33\% dalam kategori baik.

Pelaksanaan siklus II mampu memperbaiki dari siklus I . Hal ini ditunjukkan pada hasil rata-rata kelas nilai nya 79. Hal ini juga ditunjukkan pada siswa lebih aktif dalam pembelajaran, mereka melakukan diskusi untuk memecahkan masalah dengan baik, mampu bekerjasama dengan kelompok serta mampu mengerjakan soal test. Kegiatan guru pada siklus II juga menunjukkan bahwa guru lebih aktif, mampu memotivasi siswa dan mampu menjelaskan materi dengan baik serta melaksanakan perannya yang utama sebagai fasilitator dan pendamping siswa dalam melakukan diskusi untuk memecahkan suatu masalah. Berdasarkan hasil pada siklus II, maka tindakan dalam siklus dihentikan, karena hasil belajar yang diharapkan sudah maksimal dan mencapai 87,50 \% siswa yang sudah tuntas sesuai dengan indikator keberhasilan.

\section{PEMBAHASAN}

Berdasarkan hasil penelitian dengan menerapkan model pembelajaran kooperatif tipe Discovery Learning dapat meningkatkan hasil belajar kelas IV.B SD Negeri 170 Palembang. Berikut gambaran hasil penelitian dengan menerapkan Model Pembelajaran Kooperatif Tipe Discovery Learning dapat meningkatkan hasil belajar.

Tabel 3 Rekap Hasil Belajar IPA

\begin{tabular}{|c|c|c|c|}
\hline Kegiatan & $\begin{array}{c}\text { \% } \\
\text { Ketuntasan }\end{array}$ & $\begin{array}{c}\text { Jumlah } \\
\text { Ketuntasan }\end{array}$ & Nilai Rata- Rata \\
\hline Pra Siklus & 28.13 & 9 & 60.67 \\
\hline Siklus I & 59.38 & 19 & 69.00 \\
\hline Siklus II & 87.50 & 28 & 79.00 \\
\hline
\end{tabular}

Berdasarkan tabel di atas tampak bahwa hasil belajar dari pra siklus, sampai dengan siklus II mengalami peningkatan. Pada nilai pra siklus nilai ratarata 60.67. Pada siklus I hasil rata-rata yang diperoleh adalah 69.00 meningkat 
menjadi 79,00 pada siklus II .Sehingga dapat ditarik kesimpulan bahwa dengan menerapkan model pembelajaran kooperatif tipe Discovery Learning pada pembelajaran IPA siswa kelas IV SD Negeri 170 Palembang dapat meningkatkan hasil belajar. Lebih jelas dapat dilihat pada gambar di bawah ini:

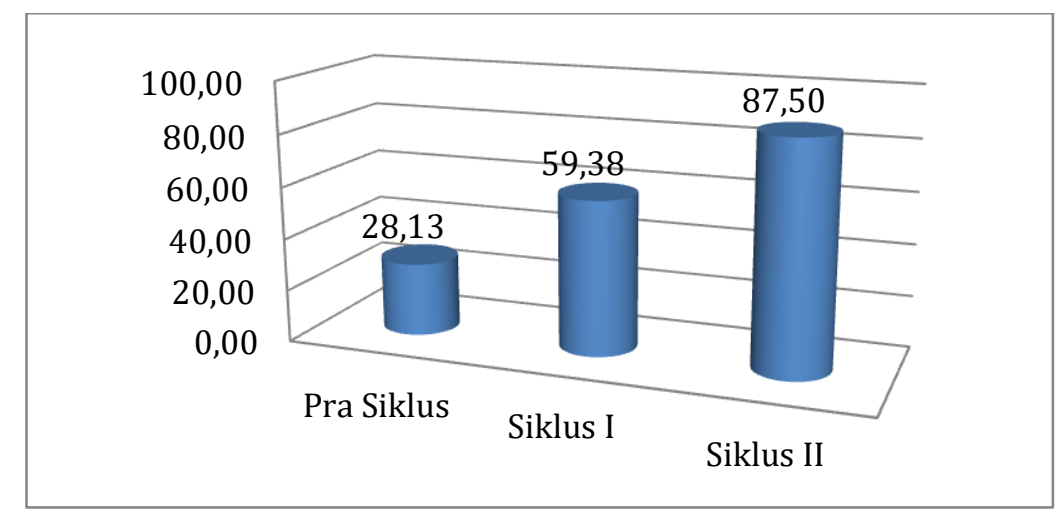

Gambar 1 Rekap hasil belajar

\section{SIMPULAN}

Pembelajaran dengan menerapkan Model pembelajaran kooperatif tipe Discovery Learning berdampak positif bagi siswa yaitu siswa menjadi aktif dalam mengikuti pembelajaran, karena pengalaman dan percobaan langsung siswa akan berpengaruh besar terhadap hasil belajar, membuat guru untuk lebih menguasai materi karena guru sebagai fasilitator harus menguasai materi dan mampu mengembangkannya serta guru sebagai motivator yang mampu memotivasi siswa untuk mengekspresikan gagasan-gagasannya dan menyediakan kesempatan dan pengalaman yang mendukung proses belajar. Terlihat pada siklus I hasil belajar yang diperoleh yang tuntas adalah 59,38\%.

Pada siklus ke II hasil belajar yang tuntas diperoleh adalah $87.50 \%$. Terlihat bahwa pada siklus II kegiatan guru dan siswa sudah melaksanakan pembelajaran dengan menerapkan model pembelajaran kooperatif tipe Discovery Learning secara maksimal sehingga hasil belajar yang diperoleh juga maksimal, sehingga dapat disimpulkan bahwa pembelajaran dengan menerapkan model pembelajaran kooperatif tipe Discovery Learning mengalami peningkatan hasil belajar yang sangat baik sesuai dengan indikator keberhasilan. 


\section{DAFTAR PUSTAKA}

Hamalik, Oemar. (2008). Dasar-Dasar Pengembangan Kurikulum. Bandung: PT Remaja Rosdakarya.

Hamalik, Oemar. (2011). Kurikulum dan Pembelajaran. Jakarta: Bumi Aksara

Ibrahim. (2009). Pembelajaran Kooperatif. Surabaya: UNESA

Murni, dkk. (2009). Penerapan Metodean Belajar Aktif Tipe Group To Group Exchange (GGE) Untuk Meningkatkan Hasil Belajar Matematika Siswa Kelas X IPS 1 MAN 2 MODEL Pekan Baru. Jurnal Penelitian Pendidikan Vol.11 No.2

Sardiman, A.M. (2005). Interaksi dan Motivasi Belajar-Mengajar. Jakarta: Erlangga.

Slameto. (2010). Belajar dan Faktor-Faktor Yang Mempengaruhi. Jakarta: PT. Rineka Cipta.

Sukidin, dkk. (2002). Manajemen Penelitian Tindakan Kelas. Surabaya: Insan Cendekia.

Samantowa, Usman. (2011). Bagaimana Membelajarkan IPA di SD. Jakarta: Depdiknas.

Sanjaya, Wina. (2009). Strategi Pembelajaran Berorientasi Standar Proses Pendidikan. Jakarta: Kencana.

Trianto. (2009). Model-Model Pembelajaran Inovatif Berorientasi Konstruktivistik. Surabaya: Prestasi Pustaka.

Winkel, W.S. (1991). Psikologi Pengajaran. Jakarta: Grasindo. 